\title{
A Randomized Controlled Trial to Assess the Effectiveness of Oral Rehydration Solution on the Natremic Status of Operated Patients with Traumatic Brain Injury
}

\author{
Renu Kumari ${ }^{1}$ Manju Dhandapani ${ }^{1}$ Sukhpal Kaur ${ }^{1}$ Navneet Singla ${ }^{2}$ Bikash Medhi ${ }^{3}$ \\ ${ }^{1}$ Department of Nursing, National Institute of Nursing Education \\ (NINE), PGIMER, Chandigarh, Punjab, India \\ 2 Department of Neurosurgery, PGIMER, Chandigarh, Punjab, India \\ Address for correspondence Manju Dhandapani, MSc, National \\ Institute of Nursing Education (NINE), PGIMER, Chandigarh, Punjab \\ 160012, India (e-mail: manjuseban@gmail.com).
}

${ }^{3}$ Department of Pharmacology, PGIMER, Chandigarh, Punjab, India

Indian J Neurosurg 2015;4:141-147.

\begin{abstract}
Keywords

- traumatic brain injury

- oral rehydration solution

- hyponatremia

- normonatremia

- hypernatremia
\end{abstract}

Background Sodium alterations are very common among patients with the postoperative traumatic brain injury (TBI). It can be hyponatremia or hypernatremia. Sodium disturbances can lead to serious complications and adverse outcomes including death.

Aim The current study was performed to assess the effectiveness of oral rehydration solution (ORS) on natremic status of patients with postoperative TBI.

Materials and Methods The study was performed in the Department of Neurosurgery of a tertiary care hospital. Total 100 patients on Ryles tube were randomly allocated. The tools used were semistructured interview schedule and biophysiologic methods. In the intervention group, administration of ORS was started on second postoperative day till fifth postoperative day. Serum sodium levels were assessed daily from zeroth postoperative day to fifth postoperative day in both groups. Statistical Analysis and Result Both the groups were homogeneous and comparable. The mean serum sodium levels before and after the intervention were not significantly different in both groups. The proportion of patients with normonatremia was significantly greater in the intervention group on third through fifth postoperative days, that is, 76,78 , and $82 \%$, as compared with that in the control group, that is, 52 , 52 , and $60 \%$. The proportion of the patients with hyponatremia was high on third through fifth postoperative days in the control group as compared with that in the intervention group. The hypernatremia developed varied from 8 to $18 \%$ in both the groups.

Conclusion Thus to prevent sodium imbalance, ORS can be safely administered to the patients with postoperative TBI without increasing the risk of hypernatremia. received

July 14, 2015

accepted

September 22, 2015

published online

December 16, 2015
DOI http://dx.doi.org/

10.1055/s-0035-1570310. ISSN 2277-954X.
(C) 2015 Neurological Surgeons' Society

of India
License terms

(ㄷ) (i) $\ominus$ (\$) 


\section{Introduction}

Traumatic brain injury (TBI) is the leading cause of injuryrelated deaths and disability among the young adults worldwide. ${ }^{1}$ Sodium disturbances are common in patients with TBI because of the major role that the central nervous system plays in the regulation of sodium and water homeostasis. Sodium disturbances can lead to serious complications and adverse outcomes, including death., ${ }^{2,3}$

In normal condition, there is a balance between sodium, retention of water, and vasopressin production. However, in case of neurosurgery patients, this balance may be disturbed as a result of increased secretion of antidiuretic hormone $(A D H)$. This syndrome results in retention of water and hyponatremia. ${ }^{4-6}$ In addition, treatment of the injured brain, that is, use of loop diuretics, osmotic diuretics, hypertonic saline, etc., can itself disturb regulation of sodium and water. Brain injury also affects the integrity of the blood-brain barrier (BBB) to varying degrees, and this may lead to alteration in the natremic status. ${ }^{4,7}$

The treatment for natremic or sodium alterations should begin as early as possible. Monitoring natremic status and clinical manifestations of altered natremic status are vital to initiate early and appropriate treatment in these patients. Treatment for water and sodium imbalance focuses on water overload and hyponatremia and consists of osmotic therapy with hypertonic saline and loop diuretics (e.g., frusemide). The management of hypernatremia is water replacement. ${ }^{8-10}$ There are not much evidences on preventive measures for the alterations in natremic status in patients with TBI. Therefore, the present study is planned to assess the effect of oral rehydration solution (ORS) on the natremic status of patients with postoperative TBI.

Appropriate fluid, electrolyte, and nutritional balance are an integral part of management of patients with TBI. ${ }^{11}$ The scientific basis for the use of ORS is the cotranspor of glucose and sodium across the intestinal membrane. ORS is simple, inexpensive, and a solution of glucose, sodium chloride, potassium chloride, and sodium citrate with various concentration. ${ }^{12}$ Researchers have used ORS in maintaining the electrolyte imbalance in patients with diarrhea and also in the preoperative state. ORS helps in the prevention of fluid and electrolyte imbalance as well as the replacement of the fluid loss. ${ }^{13,14}$ There are no evidences on effectiveness of ORS in the management of fluid and electrolyte imbalances. However, considering its beneficial effects on fluid and electrolyte imbalances, the present study was undertaken to assess the effectiveness of ORS on the natremic status of patients with postoperative TBI.

\section{Materials and Methods}

The effectiveness of ORS was assessed on 100 patients with postoperative TBI, 50 in each control and intervention groups, who were admitted in the Postgraduate Institute of Medical Education and Research, Chandigarh. The patients with postoperative TBI who met the inclusion criteria, that is, postoperative period less than 24 hours, both male and female patients of age group 18 years or more, and with Ryles tube in situ, were enrolled. And patients with hypernatremia on zeroth postoperative day and on salt supplements were excluded. They were randomized using computer-generated random table. The first 50 randomized numbers were assigned to the intervention group and other 50 to the control group. The intervention and the control groups were selected by tossing a coin. Consent was taken from the guardians after enrolling the patients. Ethical clearance was obtained from Institute Ethical Committee, and permission to conduct the study was taken from the head of the department of neurosurgery.

A semistructured interview was conducted with the patient's guardian to collect sociodemographic data, clinical data were collected from patient's medical records, and serum sodium was monitored in the standardized biochemistry laboratory of PGIMER. Based on the serum sodium, natremic status was categorized into hyponatremia $(<135 \mathrm{mEq} / \mathrm{L})$, normonatremia $(135-145 \mathrm{mEq} / \mathrm{L})$, and hypernatremia ( $>145 \mathrm{mEq} / \mathrm{L}$ ).

Research tools for the study were based on the type of data to be collected. It was developed after thorough review of literature from books, national and international journals, and with the suggestions from the experts. For the tool formulation, the researcher also used her observation during the clinical experience.

In both the groups, serum sodium values were recorded on admission, then daily from zeroth postoperative day to fifth postoperative day. In the intervention group, ORS administration was started on second postoperative day to fifth postoperative day. Patients in the control group were receiving the routine care, that is, $50 \mathrm{~mL}$ plain water after Ryles tube feed and $200 \mathrm{~mL}$ plain water in every 3 hour. Patients in the intervention group received $200 \mathrm{~mL}$ of ORS every 3 hourly (instead of water) and $50 \mathrm{~mL}$ of ORS after every Ryles tube feed. Data were analyzed using descriptive and inferential statistics, and analysis was done in SPSS version 19. Independent $t$-test was used to compare the continuous data in the control and intervention groups. Chisquare test was used to compare the categorical variables.

\section{Results}

-Table 1 highlights the sociodemographic variables of the patients in both the groups. The chi-square was used to assess homogeneity between both the groups, and it was found that both the groups were comparable and homogeneous $(p>0.05)$. The mean age of the patients was $35.8 \pm 13.7$ years and $35.38 \pm 13.0$ years in the intervention and control groups, respectively. In the intervention group, $78 \%$ were males and $22 \%$ were females; and in the control group, $84 \%$ were males and $16 \%$ were females.

- Table 2 represents the clinical profile of the patients, both in the intervention and control groups. Both the groups were comparable and homogeneous in nature on different characteristics. Maximum of the patients $(60 \%$ in the intervention group and $72 \%$ in the control group) had 
Table 1 Sociodemographic profile of the patients

\begin{tabular}{|c|c|c|c|}
\hline \multirow[t]{2}{*}{ Characteristics } & \multirow{2}{*}{$\begin{array}{l}\text { Intervention group } \\
(n=50) \\
n(\%)\end{array}$} & \multirow{2}{*}{\begin{tabular}{|l|}
$\begin{array}{l}\text { Control group } \\
(n=50)\end{array}$ \\
$n(\%)$ \\
\end{tabular}} & \multirow[t]{2}{*}{$\begin{array}{l}x^{2}, \text { df } \\
p \text { Value }\end{array}$} \\
\hline & & & \\
\hline $\begin{array}{l}\text { Age }(y) \text {, mean } \pm S D \\
\quad<30 \\
\quad 30-50 \\
>50\end{array}$ & $\begin{array}{l}35.8 \pm 13.7 \\
24(48) \\
16(32) \\
10(20)\end{array}$ & $\begin{array}{l}35.3 \pm 13.0 \\
21(42) \\
21(42) \\
8(16)\end{array}$ & $\begin{array}{l}1.09 \\
0.57\end{array}$ \\
\hline $\begin{array}{l}\text { Sex } \\
\text { Male } \\
\text { Female }\end{array}$ & $\begin{array}{l}39(78) \\
11(22)\end{array}$ & $\begin{array}{l}42(84) \\
8(16)\end{array}$ & $\begin{array}{l}0.76 \\
0.44\end{array}$ \\
\hline $\begin{array}{l}\text { Marital status } \\
\text { Married } \\
\text { Unmarried }\end{array}$ & $\begin{array}{l}17(34) \\
33(66)\end{array}$ & $\begin{array}{l}13(26) \\
37(74)\end{array}$ & $\begin{array}{l}0.76 \\
0.943\end{array}$ \\
\hline $\begin{array}{l}\text { Habitat } \\
\text { Rural } \\
\text { Urban }\end{array}$ & $\begin{array}{l}42(84) \\
8(16)\end{array}$ & $\begin{array}{l}39(78) \\
11(22)\end{array}$ & $\begin{array}{l}0.58 \\
0.44\end{array}$ \\
\hline
\end{tabular}

Table 2 Clinical profile of the patients $(n=100)$

\begin{tabular}{|c|c|c|c|c|}
\hline \multicolumn{2}{|c|}{ Clinical Variable } & \multirow{2}{*}{$\begin{array}{l}\text { Intervention group } \\
(n=50), n(\%) \\
21(42)\end{array}$} & \multirow{2}{*}{$\begin{array}{l}\text { Control group } \\
(n=50), n(\%)\end{array}$} & \multirow{2}{*}{$\begin{array}{l}x^{2} \\
p \text { Value } \\
0.04 \\
0.84\end{array}$} \\
\hline CT findings & $\mathrm{SDH}$ & & & \\
\hline & $\mathrm{EDH}$ & $14(28)$ & $21(42)$ & $\begin{array}{l}2.15 \\
0.14\end{array}$ \\
\hline & Contusion & $30(60)$ & $36(72)$ & $\begin{array}{l}0.64 \\
0.42\end{array}$ \\
\hline & Skull fracture & $9(18)$ & $13(26)$ & $\begin{array}{l}0.93 \\
0.33\end{array}$ \\
\hline & Mass effect & $34(68)$ & $27(54)$ & $\begin{array}{l}2.06 \\
0.15\end{array}$ \\
\hline & Midline shift & $28(56)$ & $26(52)$ & $\begin{array}{l}0.16 \\
0.68\end{array}$ \\
\hline \multicolumn{2}{|c|}{$\begin{array}{l}\text { Mode of injury } \\
\text { Motor-vehicle accident } \\
\text { Fall from height } \\
\text { Pedestrian accident } \\
\text { Others (assault, fall of object } \\
\text { on head) }\end{array}$} & $\begin{array}{l}26(52) \\
9(18) \\
7(14) \\
8(16)\end{array}$ & $\begin{array}{l}31(62) \\
12(24) \\
3(6) \\
4(8)\end{array}$ & $\begin{array}{l}3.6^{a} \\
0.31\end{array}$ \\
\hline \multicolumn{2}{|c|}{$\begin{array}{l}\text { Interval between injury and admission } \\
\text { to hospital (h) } \\
\quad 0-6 \\
7-12 \\
>12\end{array}$} & $\begin{array}{l}38(76) \\
8(16) \\
4(8)\end{array}$ & $\begin{array}{l}42(84) \\
7(14) \\
1(2)\end{array}$ & $\begin{array}{l}1.94^{\mathrm{a}} \\
0.46\end{array}$ \\
\hline \multicolumn{2}{|c|}{$\begin{array}{l}\text { Blood loss during surgery }(\mathrm{mL}) \\
\quad 100-300 \\
301-600 \\
>600\end{array}$} & $\begin{array}{l}17(34) \\
25(50) \\
8(16)\end{array}$ & $\begin{array}{l}14(28) \\
25(50) \\
11(22)\end{array}$ & $\begin{array}{l}0.76(2)^{\mathrm{a}} \\
0.69\end{array}$ \\
\hline \multicolumn{2}{|c|}{$\begin{array}{l}\text { Severity of head injury } \\
\text { Severe }(3-8) \\
\text { Moderate }(9-12) \\
\text { Mild (13-15) }\end{array}$} & $\begin{array}{l}34(68) \\
13(26) \\
3(6)\end{array}$ & $\begin{array}{l}33(66) \\
13(26) \\
4(8)\end{array}$ & $\begin{array}{l}0.23(2)^{\mathrm{a}} \\
1.00\end{array}$ \\
\hline
\end{tabular}

Abbreviations: $\mathrm{CT}$, computed tomography; $\mathrm{EDH}$, extradural hematoma; $\mathrm{SDH}$, subdural hematoma.

${ }^{\mathrm{a}}$ Fisher exact test. 
Table 3 Mean serum sodium values: Intervention versus control group $(n=100)$

\begin{tabular}{|l|l|l|l|l|}
\hline Number of POD & \multicolumn{2}{|l|}{ Sodium levels (mEq/L) } & $t$ Value & $p$ Value \\
\hline & $\begin{array}{l}\text { Intervention group } \\
\text { (mean } \pm \text { SD), } \boldsymbol{n}=50\end{array}$ & $\begin{array}{l}\text { Control group } \\
\text { (mean } \pm \text { SD), } \boldsymbol{n}=50\end{array}$ & & \\
\hline 0th & $140.1 \pm 3.4$ & $140.2 \pm 3.4$ & 1.98 & 0.84 \\
\hline 1st & $139.7 \pm 4.2$ & $140.6 \pm 5.2$ & 0.92 & 0.35 \\
\hline 2nd & $139.7 \pm 5.0$ & $138.6 \pm 5.6$ & 1.02 & 0.30 \\
\hline 3rd & $140.5 \pm 4.2$ & $138.5 \pm 6.7$ & 1.77 & 0.07 \\
\hline 4th & $140.8 \pm 3.8$ & $139.8 \pm 6.8$ & 0.95 & 0.34 \\
\hline 5th & $140.5 \pm 4.1$ & $139.3 \pm 6.5$ & 1.03 & 0.24 \\
\hline
\end{tabular}

Abbreviations: POD, postoperative day; SD, standard deviation.

contusions. Mass effect was present in $68 \%$ of patients in the intervention group and $54 \%$ in the control group. Midline shift was present in 56 and $52 \%$ in the intervention and control groups, respectively.

Fifty-two percent patients in the intervention group and $62 \%$ in the control group sustained TBI due to motor-vehicle accident, and $76 \%$ in the intervention group and $84 \%$ in the control group were admitted in the hospital within 6 hours of injury. Fifty percent patients each in the intervention and control groups had 300 to $600 \mathrm{~mL}$ blood loss during surgery. Most patients, that is, 68\% in the intervention and 66\% in control groups, sustained severe head injury.

- Table 3 reveals the mean of serum sodium value from the day of admission to fifth postoperative days. Independent $t$-test was used to compare the same in both the groups. There was no significant difference between the means of serum sodium values in any of the postoperative day.

As shown in the - Table $\mathbf{3}$, the preintervention serum sodium values from zeroth postoperative day till second postoperative day were comparable between the intervention and control groups. The ORS administration was started in the intervention group from second postoperative day. There was no significant difference in the postintervention serum sodium values on third through fifth postoperative days between the intervention and control groups.

- Table 4 shows the distribution of the patients based on the natremic status in different postoperative days, and there was no significant difference between both the groups before starting the intervention, that is, on zeroth to second postoperative day. It was also found that the proportion of the patients with normal natremic status had been decreasing since zeroth postoperative day to second postoperative day in both the intervention and control groups, that is, from $82 \%$ in the intervention group to $74 \%$ and from $88 \%$ in the control group to $70 \%$. In the intervention group after the administration of ORS, the proportion of the patients with normonatremia started increasing on third through fifth days, that is, 76, 78, and $82 \%$; but in the control group, the proportion of patients with normonatremia kept decreasing, that is, 52, 52, and $60 \%$. As shown in the table, proportion of patients with normonatremia was significantly greater in the intervention group on third through fifth postoperative days.

In the intervention group, the proportion of patients with hyponatremia remained 16 to $-18 \%$ before intervention and was only 8 to $12 \%$ after intervention. However, in the control group, the proportion of the patients with hyponatremia was increased up to $34 \%$ during the postoperative period. The proportion of the patients with hyponatremia was significantly high on third through fifth postoperative days, that is, 34,30 , and $26 \%$ in the control group as compared with 12,10 , and $8 \%$ in intervention group.

None of the patients were hypernatremic on zeroth day in both the groups. The proportion of the patients with hypernatremia remained similar in both the groups before and after intervention.

- Table 5 depicts the proportion of the patients with normal and abnormal (hypo or hyper) natremic status in both the intervention and control groups pre- and postintervention. There was no significant difference in natremic status between both the groups before intervention. However, after the intervention, the proportion of the patient with abnormal natremic status was significantly high on third through fifth postoperative days in the control group. When 48,48 , and $40 \%$ of patients in the control group had altered serum sodium level, only 24,22 , and $18 \%$ in the intervention group had the same on third through fifth postoperative days, respectively.

\section{Discussion}

Even though the brain is a well-protected structure, it may be injured by a blow to the head or by penetration of any object that disrupts the normal function of the brain. Damage to the brain may occur immediately or it may develop after the injury due to the swelling or bleeding leading to the biochemical changes in the brain, which results in electrolyte and nutritional imbalance. ${ }^{4,5,15}$ Patients with biochemical and nutritional imbalances, which is influenced by severity of injury, are found to have 
Table 4 Distribution of patients based on the serum sodium levels $(n=100)$

\begin{tabular}{|c|c|c|c|c|}
\hline Number of POD & $\begin{array}{l}\text { Characteristics } \\
\text { (natremic status) }\end{array}$ & $\begin{array}{l}\text { Intervention group } \\
n=50, n(\%)\end{array}$ & $\begin{array}{l}\text { Control group } \\
n=50, n(\%)\end{array}$ & $\begin{array}{l}x^{2} \\
p \text { Value }\end{array}$ \\
\hline 0th & $\begin{array}{l}\text { Hyponatremia } \\
\text { Normonatremia }\end{array}$ & $\begin{array}{l}9(18) \\
41(82)\end{array}$ & $\begin{array}{l}6(12) \\
44(88)\end{array}$ & $\begin{array}{l}0.70 \\
0.40\end{array}$ \\
\hline $1 \mathrm{st}$ & $\begin{array}{l}\text { Hyponatremia } \\
\text { Normonatremia } \\
\text { Hypernatremia }\end{array}$ & $\begin{array}{l}8(16) \\
38(76) \\
4(8)\end{array}$ & $\begin{array}{l}6(12) \\
39(78) \\
5(10)\end{array}$ & $\begin{array}{l}{ }^{\mathrm{a}} 0.47 \\
0.88\end{array}$ \\
\hline 2nd & $\begin{array}{l}\text { Hyponatremia } \\
\text { Normonatremia } \\
\text { Hypernatremia }\end{array}$ & $\begin{array}{l}9(18) \\
37(74) \\
4(8)\end{array}$ & $\begin{array}{l}10(20) \\
35(70) \\
5(10)\end{array}$ & $\begin{array}{l}{ }^{\mathrm{a}} 0.21 \\
0.89\end{array}$ \\
\hline $3 r d$ & $\begin{array}{l}\text { Hyponatremia } \\
\text { Normonatremia } \\
\text { Hypernatremia }\end{array}$ & $\begin{array}{l}6(12) \\
38(76) \\
7(14)\end{array}$ & $\begin{array}{l}17(34) \\
26(52) \\
7(14)\end{array}$ & $\begin{array}{l}7.58 \\
{ }^{\mathrm{b}} 0.02\end{array}$ \\
\hline 4th & $\begin{array}{l}\text { Hyponatremia } \\
\text { Normonatremia } \\
\text { Hypernatremia }\end{array}$ & $\begin{array}{l}5(10) \\
39(78) \\
6(12)\end{array}$ & $\begin{array}{l}15(30) \\
26(52) \\
9(18)\end{array}$ & $\begin{array}{l}8.20 \\
{ }^{\mathrm{b}} 0.01\end{array}$ \\
\hline 5th & $\begin{array}{l}\text { Hyponatremia } \\
\text { Normonatremia } \\
\text { Hypernatremia }\end{array}$ & $\begin{array}{l}4(8) \\
41(82) \\
5(10)\end{array}$ & $\begin{array}{l}13(26) \\
30(60) \\
7(14)\end{array}$ & $\begin{array}{l}6.88 \\
{ }^{\mathrm{b}} 0.03\end{array}$ \\
\hline
\end{tabular}

Abbreviation: POD, postoperative day.

${ }^{\mathrm{a}}$ Fishers exact test.

${ }^{\mathrm{b}} p$ Value $<0.05$

Table 5 Distribution of patients based on normal and abnormal natremic status $(n=100)$

\begin{tabular}{|c|c|c|c|c|}
\hline Number of POD & Natremic status & $\begin{array}{l}\text { Intervention group } \\
n=50, n(\%)\end{array}$ & $\begin{array}{l}\text { Control group } \\
n=50, n(\%)\end{array}$ & $\begin{array}{l}x^{2} \\
p \text { value }\end{array}$ \\
\hline 0th & $\begin{array}{l}\text { Normal } \\
\text { Abnormal }\end{array}$ & $\begin{array}{l}41(82) \\
9(18)\end{array}$ & $\begin{array}{l}44(88) \\
6(12)\end{array}$ & $\begin{array}{l}0.70 \\
0.40\end{array}$ \\
\hline $1 \mathrm{st}$ & $\begin{array}{l}\text { Normal } \\
\text { Abnormal }\end{array}$ & $\begin{array}{l}38(76) \\
12(24)\end{array}$ & $\begin{array}{l}39(78) \\
11(22)\end{array}$ & $\begin{array}{l}0.05 \\
0.81\end{array}$ \\
\hline 2nd & $\begin{array}{l}\text { Normal } \\
\text { Abnormal }\end{array}$ & $\begin{array}{l}37(74) \\
13(26)\end{array}$ & $\begin{array}{l}35(70) \\
15(30)\end{array}$ & $\begin{array}{l}0.19 \\
0.65\end{array}$ \\
\hline $3 r d$ & $\begin{array}{l}\text { Normal } \\
\text { Abnormal }\end{array}$ & $\begin{array}{l}38(76) \\
12(24)\end{array}$ & $\begin{array}{l}26(52) \\
24(48)\end{array}$ & $\begin{array}{l}6.25 \\
{ }^{a} 0.01\end{array}$ \\
\hline 4th & $\begin{array}{l}\text { Normal } \\
\text { Abnormal }\end{array}$ & $\begin{array}{l}39(78) \\
11(22)\end{array}$ & $\begin{array}{l}26(52) \\
24(48)\end{array}$ & $\begin{array}{l}7.64 \\
\mathrm{a} 0.006\end{array}$ \\
\hline 5th & $\begin{array}{l}\text { Normal } \\
\text { Abnormal }\end{array}$ & $\begin{array}{l}41(82) \\
9(18)\end{array}$ & $\begin{array}{l}30(60) \\
20(40)\end{array}$ & $\begin{array}{l}8.57 \\
{ }^{a} 0.01\end{array}$ \\
\hline
\end{tabular}

Abbreviation: POD, postoperative day.

${ }^{a} p$ Value $<0.05$

higher morbidity and mortality. ${ }^{15-17}$ Sodium is the main electrolyte that undergoes alterations after TBI as the brain plays an important role in maintaining electrolyte balance. ${ }^{2}$

TBI can occur at any age, but the peak incidences are among people between the ages of 15 and 24. In the present study, maximum of the patients with TBI are in the age group of 18 to 30 years. Although motor-vehicle accidents are the leading of TBIs, accounting for nearly $50 \%$ of all the cases, fall, violent assault, and others also remain the cause for it. ${ }^{6,7}$ In the present study also, motor-vehicle accidents were the leading cause, that is, $52 \%$ in the intervention group and $62 \%$ in the control group followed by falls, pedestrian accident assault, etc.

In healthy adults, the water balance is largely controlled by posterior pituitary hormone-vasopressin or $\mathrm{ADH}$. In case of neurosurgery patients, the balance between sodium retention, retention of water, and vasopressin production may be disturbed as a result of increased secretion of ADH. ${ }^{18,19}$ This syndrome results in retention of water and hyponatremia. ${ }^{9,16}$ Breakdown of the BBB due to injury also leads to changes in the natremic status of the patents with TBI. $^{4}$ 
The patients with brain injury were at a risk of developing electrolyte imbalances, and the most common was hyponatremia. Sodium was the main electrolyte that underwent change among the patients with severe TBI. Sodium disturbances were reported in 33 to $75 \%$ of patients with TBI between 4 and 16 days after trauma.,20-22 Correction of hyponatremia at the earliest is mandatory due to its adverse effect on the brain. ${ }^{23}$ In present study, a maximum of $34 \%$ in control group and only $12 \%$ in the intervention group had hyponatremia on the third postoperative day.

In the current study, both the groups were comparable as per their sociodemographic variables, clinical profile, and preintervention sodium level. The mean serum sodium levels in the intervention and control groups remained within the normal range varying from 138 to $140 \mathrm{mEq} / \mathrm{L}$, and there was no significant difference between both the groups throughout the study.

However, in the categorical analysis, it was found that the proportion of the patients with normal natremic status was significantly higher on third through fifth postoperative days in patients who received ORS. The proportion of the patients with hyponatremia was significantly low on third through fifth postoperative day in the intervention group as compared with the control group. The hypernatremia developed in both the groups varied from 8 to $18 \%$, and there was no significant difference in both the groups throughout the study.

Administration of ORS helps in the volume replacement as well as electrolyte replacement, which helps in maintaining the normal natremic status ${ }^{12}$ and preventing hyponatremia that is common among patients with TBI due to cerebral salt-wasting syndrome, syndrome of inappropriate secretion of $\mathrm{ADH}$, and various other causes. ${ }^{4}$ When ORS is administered, a mechanism of co-transport of glucose and sodium helps in the absorption of sodium and also in maintenance of normal natremic status. ${ }^{13}$ Thus it may also helps in the prevention of complications related to hyponatremia in patients with TBI.

The role of ORS in the correction of natremic alterations in TBI is not known. However, according to the present study findings, ORS reduces the incidence of natremic alterations, especially hyponatremia in patients with postoperative TBI who are at the risk for the same. The proportion of patient with hypernatremia was equal in both the groups. ORS has certain advantages; for example, it contains electrolytes in balanced quantity, it is cheap, easily available, easy to prepare, administered orally or via Ryles tube, and can be given to any age group. ${ }^{12}$

Disturbances of plasma sodium concentration warrant close attention in patients with craniocerebral injuries to allow timely and appropriate therapeutic intervention and prevent possible complications that may exacerbate conditions eventually leading to death., ${ }^{3,4}$ Disturbance in plasma sodium concentration may be due to the secondary injuries, and functional brain imaging techniques may be useful to assess hemodynamic or metabolic changes within the brain and are especially helpful in the subacute phase of injury when secondary injury is developing. ${ }^{24,25}$ Early identification of secondary injury will aid in early initiation of treatment modalities. ${ }^{24}$

Hence, based on the present study, ORS can be administered to the patients with postoperative TBI to maintain the natremic status and reduce hyponatremia without increasing the risk of hypernatremia. However, further studies are required for the safe implication of this research study in practice.

\section{Conclusion}

Electrolyte imbalance especially natremic alterations are very common in the patient with TBI. Therefore, some preventive strategies that are safe, cost-effective, and easily available should be used to prevent the natremic alterations. According to the present study, ORS administration is effective and safe to maintain normonatremia in the patients with postoperative TBI. The prevention of electrolyte imbalance and its consequences is essential in improving the patient outcome.

\section{Note}

Some additional information pertaining to this study is as follows:

Source of support: Nil.

CTRI Reference number for this research study: REF/2015/

02/008522. Name of the registry: Registry clinical trial.

\section{Acknowledgments}

I thank my patients having TBI and their caregivers without whose cooperation this project would not have been possible.

\section{References}

1 Dhandapani SS, Manju D, Sharma BS, Mahapatra AK. Clinical malnutrition in severe traumatic brain injury: factors associated and outcome at 6 months. Indian J Neurotrauma 2007;4(1): 35-39

2 Bradshaw K, Smith M. Sodium imbalance after brain injury [article online]. 2008. http://caecep.oxfordjournals.org. Retrieved and cited January 20, 2014

3 Fluid and electrolyte imbalance. http://en.wikipedia.org/wiki/ fluidandelectrolyteimbalance. Retrieved October 3, 2014

4 Hickey JV. The Clinical Practice of Neurological and Neurosurgical Nursing. 6th ed. Philadelphia, PA: Lippincott Publishers; 2009: 201-213, 373-406

5 Smeltzer CS, Bare B. Management of Patients with Neurologic Trauma. In: Brunner and Suddarth, eds. Text Book of Medical Surgical Nursing. 10th ed. New Delhi, India: Lippincott Williams \& Wilkins; 2004:249-258, 1911-1917

6 Youmans JR. Neurological Surgery. 4th ed, vol. 3. W.B. Saunders; 1996:1704-1705

7 Dhandapani S, Goudihalli S, Mukherjee KK, et al. Prospective study of the correlation between admission plasma homocysteine levels and neurological outcome following subarachnoid hemorrhage: a case for the reverse epidemiology paradox? Acta Neurochir (Wien) 2015;157(3):399-407 
8 Traumatic brain injury: hope through research. Available at: http://www.ninds.nih.gov/disorders/tbi/detail_tbi.html. Retrieved January 13, 2014

9 Viliunas Vida. Postoperative hyponatremia. European J Endocrinol. http://www.anzca.edu.au/training/2013-trainingprogram/pdfs/anaesthesia-training-program-curriculum.pdf. Retrieved January 13, 2014

10 Diringer MN, Zazulia AR. Hyponatremia in neurologic patients: consequences and approaches to treatment. http://www.ncbi.nlm. nih.gov/pubmed?cmd=Link\&dbFrom=PubMed\&from_uid= 6839240. Retrieved March 10, 2014

11 Dhandapani SS, Manju D, Mahapatra AK. The economic divide in outcome following severe head injury. Asian J Neurosurg 2012; 7(1):17-20

12 Oral Rehydration Therapy. Wikipedia. en.wikipedia.org/wik/ oral_rehydration. Retrieved January 20, 2014

13 Munos KM, Walker CLF, Black RE. The effect of oral rehydration solution and recommended home fluids on diarrhea mortality. Int J Epidemiol. http://ije.oxfordjournals.org/content/39/suppl_1/ i75. Retrieved July 2, 2014

14 Taniguchi H, Sasaki T, Fujita H. Oral rehydration therapy for preoperative fluid and electrolyte management. Int J Med Sci. http://www.medsci.org/v08p0501.html. Retieved. January 12, 2015

15 Dhandapani M, Dhandapani S, Agarwal M, Mahapatra AK. Pressure ulcer in patients with severe traumatic brain injury: significant factors and association with neurological outcome. J Clin Nurs 2014;23(7-8):1114-1119

16 Dhandapani SS, Manju D, Vivekanandhan S, Agarwal M, Mahapatra AK. Prospective longitudinal study of biochemical changes in critically ill patients with severe traumatic brain injury: factors associated and outcome at 6 months. Indian J Neurotrauma 2010;7(1):23-27
17 Dhandapani S, Sarda AC, Kapoor A, Salunke P, Mathuriya SN, Mukherjee KK. Validation of a new clinico-radiological grading for compound head injury: implications on the prognosis and the need for surgical intervention. World Neurosurg 2015;84(5):1244-1250

18 Hardman JM, Manoukian A. Pathology of head trauma. Neuroimaging Clin N Am 2002;12(2):175-187, vii

19 Born JD, Hans P, Smitz S, Legros JJ, Kay S. Syndrome of inappropriate secretion of antidiuretic hormone after severe head injury. Surg Neurol 1985;23(4):383-387

20 Saied A, Safavi M, Tavakoli DM, Honarmand A. Predisposing factors for serum sodium disturbances in patients with severe traumatic brain injury. Turk J Med Sci. http://www.journals. tubitak.gov.tr/medical/issues/sag-10.../sag-40-6-4-0908-02.pdf. Retrieved February 12, 2015

21 Rafiq MF, Ahmed N, Khan AA. Serum electrolyte derangements in patients with traumatic brain injury[Abstract online]. J Ayub Med Coll Abbottabad 2013 Jan;25(1-2):162-164. Cited January 20, 2015. http://www.ncbi.nlm.nih.gov/pubmed/ 25098085. Cited January 20, 2015

22 Paiva WS, Bezerra DA, Amorim RL, et al. Serum sodium disorders in patients with traumatic brain injury. Ther Clin Risk Manag 2011;7:345-349

23 Adiga US, Vickneshwaran V, Sen SK. Electrolyte derangements in traumatic brain injury. Basic Res J 2012;1(2):15-18

24 Dhandapani S, Sharma A, Sharma K, Das L. Comparative evaluation of MRS and SPECT in prognostication of patients with mild to moderate head injury. J Clin Neurosci 2014;21(5):745-750

25 Dhandapani S, Kapoor A, Gaudihalli S, Dhandapani M, Mukherjee KK, Gupta SK. Study of trends in anthropometric nutritional indices and the impact of adiposity among patients of subarachnoid hemorrhage. Neurol India 2015;63(4): $531-536$ 